\title{
Inform What Really Matters
}

\section{Dion Dewa Barata}

Institut Teknologi dan Bisnis Kalbis. Indonesia

dion.dewa@kalbis.ac.id

\section{Doi:10.5901/mjss.2015.v6n5s5p58}

\begin{abstract}
The aim of this study was to determine the information mix that is really needed by potential tourists before they travel to Europe and other Mediteranian region. The scope of this research was on pre-visit behavior conducted by tourist based on information they had. This study used two research approaches. A qualitative approach was done by conducting focus group discussions involving 75 informants from five major cities in Indonesia to determine the composition of the information mix that are important to potential tourists. Quantitative Approach done by distributing questionnaires to 270 respondents from five major cities in Indonesia to confirm the information mix and research models developed based on the results of focus group discussions. Data processing using structure equation modeling found that place information mix has an influence on place perception but had no effect on place connectiveness. Place perception also found to affect place connectiveness, intention to visit, and pre-visit action. It was also found that the pre-visit action was affected by place connectiveness and intention to visit. Based on the expected results, the tourist destination authority can arrange more targeted, efficient and effective marketing strategy. The right strategy will help create a competitive advantage in a tourist destination in the competition to win the hearts of potential tourists to visit.
\end{abstract}

Keywords: Strategy, Marketing, Communication, Tourism, Information, Perception

\section{Background}

The development of the tourism industry in Indonesia increased considerably in recent years. Although the industry is highly sensitive to changes in conditions, which occur both internally and externally, the interest for travelling continues to grow and contribute to the economic, social and cultural, (Gegel, 2006). It is certainly not free from easily obtaining information through technology, which encourages tourists to not only visit a tourist destination, but more than that, together with the cultural experience, habits, art, and local life pattern of tourist destination. (Hudson, 2009).

In the context of the tourism industry in Indonesia, the data from 2009 to 2013 shows that there is a significant increasing trend of Indonesian tourists who traveled abroad, with an average length of stay over 6 days.

Table 1. Indonesian National Tourist Growth

\begin{tabular}{|c|c|c|c|c|c|c|}
\hline \multirow[t]{2}{*}{ Year } & \multicolumn{2}{|c|}{$\begin{array}{c}\text { Indonesia Tourist } \\
\text { (international outbound) }\end{array}$} & \multirow{2}{*}{$\begin{array}{c}\text { Average Spending } \\
\text { Per visit }\end{array}$} & \multirow{2}{*}{$\begin{array}{c}\text { (per person/USD) } \\
\text { Per day }\end{array}$} & \multirow[t]{2}{*}{ Average Stay (day) } & \multirow[t]{2}{*}{ Total Spending (million USD) } \\
\hline & Total person & Growth \% & & & & \\
\hline 2009 & 5.053 .269 & 1.13 & 977,39 & 109,80 & 8.81 & $4,393,00$ \\
\hline 2010 & 6.235 .606 & 23.40 & 976,65 & 117,59 & 8.20 & $6,090,00$ \\
\hline 2011 & 6.750 .416 & 8.26 & 934,50 & 121,53 & 7.67 & $6,308,26$ \\
\hline 2012 & 7.453 .633 & 10.42 & 926,20 & 127,00 & 7.67 & $6,903,55$ \\
\hline 2013 & 7.973 .443 & 9.07 & 912,32 & 143,39 & 6.49 & $7,274,55$ \\
\hline
\end{tabular}

The number of tourists is still able to increase when added with the number of Indonesian people who travel abroad for any purpose other than vacation, for example, to perform activities of MICE (meetings, incentive, conference, and exhibition). Although not specifically dedicate his foreign visit as a form of leisure, MICE activities would also be able to bring in foreign exchange for the place of tourist destination. Nevertheless, fundamental questions, which also the objectives of this study, need to be asked in order to successfully attract residents of Indonesia to visit his country; what information is considered important as a basis for decision making purposes to select the destination of a journey? 


\section{The Tourism Industry and Marketing Strategy}

The success of the tourism industry is highly dependent on the cooperation among stakeholders to produce a mutually synergetic value. According Schmoll in Toeti (2006), critical success factors of a local tourism industry are their unique tourism product and the existence of a proper marketing strategy and sustainable to communicate with potential tourists. Furthermore, according Ubjaan (2008), the marketing strategy involves a mix between several variables such as attractions, facilities, accessibility, publicity, cruise, study, and relatives. For potential tourists themselves, according to tourism activities Pitana et al. (2005) is intended as an activity looking for something that is not yet known, exploring new territory, looking for changes in the atmosphere, or getting a new journey undertaken by tourists, which is temporary in order to get pleasure, vacation or just free time.

Information submitted as part of a marketing campaign, according to Govers et al. (2007), it is necessary to consider at least two factors, namely that information should be projecting the true identity of a tourist destination. A further factor is the support of alternative sources of information, which helps promotion activities, to strengthen the image given. Thus it can be said that the interaction between potential tourists and a tourist destination is required to establish potential tourists desire to travel. Buhalis (2000) states that the right marketing strategies needed to build an integrated experience to consumers. In line with the development of information technology and differences in cultural context, it is important to do that the research would find out what information is needed for potential tourists before conducting the tour.

\section{Method}

This study uses a mixed method between qualitative and quantitative. Mixed method could give the opportunity to expand the scope or breadth of research to offset the weaknesses of either approach alone (Blake 1989; Greene et al. 1989, Rossman and Wilson 1991), which also provide pragmatic advantages when exploring complex research questions (Driscoll et al. 2007). Mixed method have been used for assessing and monitoring the impacts of recreation and tourism on the physical environment (Mackay 2004).

Some techniques for and outcomes from mixed methods research designs involving quantitizing qualitative data. According to Driscoll et al. (2007) the qualitative data provide a deep understanding of survey responses, and statistical analysis can provide detailed assessment of patterns of responses. In this research the first approach is to conduct fifteen times focus group activities involving seventy-five speakers from five major cities in Indonesia, which will travel to Europe and Mediterranean region. All sources used are the potential tourists who had planned and purchased travel packages to Europe and Mediterranean region hence they have a good experience and insight to be involved in this study. All the informants have been given several questions about the need for the information they needed for decision-making process to choose a tourist destination, followed by their behavior after obtaining such information. The result then grouped and given a weighting based on their assessment of the influence of each of these responses on voting behavior tourist destination. Based on the results of the focus group discussion, then in-depth interviews were conducted to get an overview of the relationship between each group answers. Based on the results of the response, this research put forward the following model shown in figure 1.

Availability of adequate information about a tourist destination is needed by prospective tourists, so they have an idea of the tourist destination and is able to determine whether a tourist destination in well-matched with their characteristics or not. Complete information will make potential tourists easier to build the perception of the place destination. Thus, the first hypothesis in this study is the place information mix has a positive influence on the place perception. Sufficient information about place destination can also assist prospective tourists to imagine him in the situation as if it had been in place to be addressed before. If the tour is a repeated trip, sufficient information will be helpful for potential tourists to reinforce the memory of the tourist destination. The existence of this experience, real or imaginary experience, will form a strong sense of connectedness between prospective travelers with the tourist destination. Thus the second hypothesis in this study is the place information mix has a positive influence on the place connectedness. 


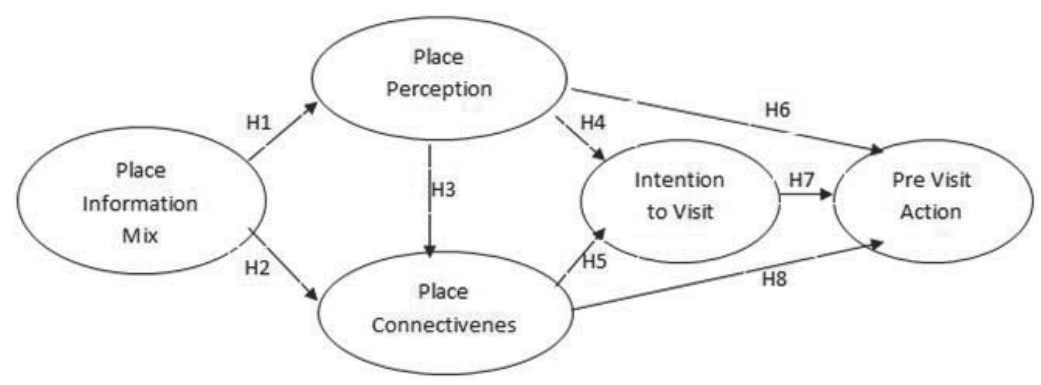

Figure 1. Research Models

Perception is awakened in the minds of potential tourists that will strengthen the assessment potential tourists on an area. Assessment is getting better, which is reflected in the perception of potential tourists, to encourage them to become more familiar with the tourist destination which in turn encourages the growth of entanglement between prospective travelers with tourist destination. so that the third hypothesis in this study is the place perception has a positive influence on the place connectiveness. Good perception on a tourist destination will also encourage the growth of the desire of potential tourists to visit the place. Thus the fourth hypothesis of this study is the place perception has a positive influence on the intention to visit a local excursions. Intention to visit a tourist destination can also be awakened by a strong attachment between prospective travelers with tourist destination. Potential tourists will try to realize the emotional attachment with their tourist destination by building a desire to visit the area. Thus the fifth hypothesis of this study is the place connectivenss have a positive influence on the intention to visit a particular destination.

Pre-visit action is a form of action that shows the seriousness to visit tourist destination. This action can be seen from the search process tickets, booking accommodation, travel preparation and so on. This process will be faster carried out by potential tourists when they already have a good perception of the tourist destination, so the sixth hypothesis in this study is the place perception has a positive influence on the pre-visit action potential tourists. Pre-visit action will also be performed by potential tourists when their intention to visit a tourist destination is getting stronger. Thus the seventh hypothesis in this study is the intention to visit has a positive influence on pre-action potential tourists visit. Great feelings tied to a tourist destination will encourage prospective tourists desire to visit the area in an effort to appreciate the sense of attachment in a tangible form. So that the last hypothesis in this study is the place connectiveness has a positive influence on the pre-visit action of potential tourists.

A quantitative approach is used to test the model by conducting a non probability sampling method to 270 potential tourists who are in the waiting period departure tourist trip to Europe and Mediterranean region, from five major cities in Indonesia, which is equal to the qualitative stage. Reliability testing is done by looking at the value of Cronbach alpha and based on the results of data collection is stated that all the variables in this study are reliable because all variables have a Cronbach alpha values above the required value of 0.7 (Heir et al. 2005)

Table 2. Reliability test

\begin{tabular}{lcl}
\hline Variables & Cronbach Alpha & Remark \\
\hline Place Information Mix & 0,872 & Reliable \\
Place Perception & 0,891 & Reliable \\
Place Connectiveness & 0,824 & Reliable \\
Intention to Visit & 0,857 & Reliable \\
Pre Visit Action & 0,783 & Reliable \\
\hline
\end{tabular}

Calculations using Structural Equation Modeling (SEM) was performed in this study because, according to Byrne (2001), SEM can describe a causal process with multiple variables at once. Based on the measurement model, all the factors that are used was considered valid because it has a loading factor of sufficient value that exceeds 0.50 . 
Table 3. Measurement Model

\begin{tabular}{llcc}
\hline Variables & Indicators & Standardized Factor Loading & Remark \\
\hline Place Information Mix & Story (M1) & 0,872 & Valid \\
& Access (M2) & 0,632 & Valid \\
& Infrastructure (M3) & 0,864 & Valid \\
& Locals (M4) & 0,722 & Valid \\
& Finance (M5) & 0,587 & Valid \\
& Event (M6) & 0,721 & Valid \\
Place Perception & Financial Investment (P1) & 0,689 & Valid \\
& Cultural Heritage (P2) & 0,620 & Valid \\
& Ambience (P3) & 0,891 & Valid \\
& Social Atmosphere (P4) & 0,782 & Valid \\
Place Connectiveness & Social Pride (C1) & 0,870 & Valid \\
& Pre-visit WOM (C2) & 0,641 & Valid \\
& Related Story (C3) & 0,810 & Valid \\
& Sense of Belonging(C4) & 0,620 & Valid \\
Intention to Visit & Scheduling (I1) & 0,582 & Valid \\
& Travel Ittenary (I2) & 0,701 & Valid \\
& Budget Allocation (I3) & 0,680 & Valid \\
& Specific Information Search (14) & 0,772 & Valid \\
Pre-Visit Action & Ticket Purchase (A1) & 0,735 & Valid \\
& Accommodation Booking (A2) & 0,814 & Valid \\
& Legal Administrative (A3) & 0,620 & Valid \\
& Social Arrangement (A4) & 0,782 & Valid \\
\hline
\end{tabular}

Hypothesis testing can be seen in figure 3 is done by using the structural model, can be seen in the picture of the structural model, to see the value of its critical ratio, where there are seven accepted hypothesis and one hypothesis is not accepted because it does not meet the requirements of greater than \pm 1.96 for $95 \%$ confidence level.

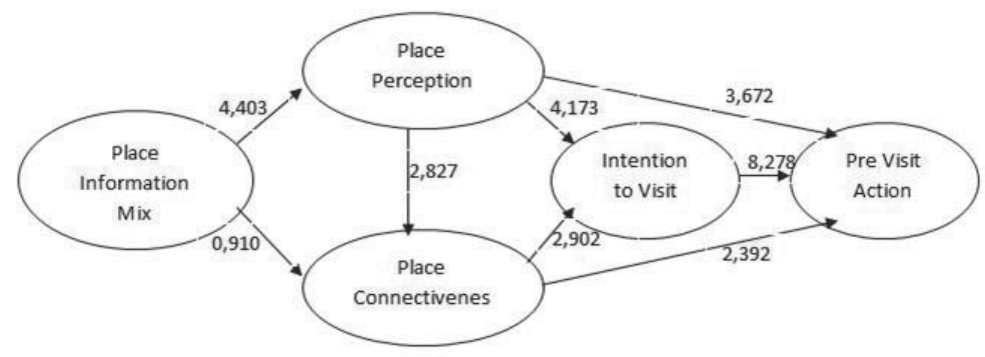

Figure 2. Structural Model

More complete testing of hypothesis can be seen in Table 3 below:

Table 4. Hypothesis Test

\begin{tabular}{lll}
\hline Hypothesis & T Value & Remarks \\
\hline place information mix has positive influence to place perception. $(\mathrm{H} 1)$ & 4,403 & Hypothesis accepted \\
\hline place information mix has positive influence to place connectiveness. $(\mathrm{H} 2)$ & 0,910 & Hypothesis not accepted \\
\hline place perception has positive influence to place connectiveness. $(\mathrm{H} 3)$ & 2,827 & Hypothesis accepted \\
\hline place perception has positive influence to intention to visit. $(\mathrm{H} 4)$ & 4,173 & Hypothesis accepted \\
\hline place connectivenss has positive influence to intention to visit. $(\mathrm{H} 5)$ & 2,902 & Hypothesis accepted \\
\hline place perception has positive influence to pre-visit action. $(\mathrm{H} 6)$ & 3,672 & Hypothesis accepted \\
\hline intention to visit has positive influence to pre-visit action. $(\mathrm{H} 7)$ & 8,278 & Hypothesis accepted \\
\hline place connectiveness has positive influence to pre-visit action. $(\mathrm{H} 8)$ & 2,392 & Hypothesis accepted \\
\hline
\end{tabular}




\section{Analysis}

In this study, pre-visit place visible action is influenced by three variables: place perception, intention to visit, and place conectiveness. The formation of a positive perception by potential tourists to a tourist destination it can encourage prospective tourists desire to take real action in order to prepare for his journey to the marketing strategy of a tourist destination needs to be designed in order to be able to communicate superiority or uniqueness that can build a good perception. Better emotional bond between potential tourists to tourist destinations also have an influence on the emergence of a real action to prepare a tourist trip.

The emergence place connectivenss an interesting phenomenon because this connectiveness arises not because of the experience of visiting a certain tourist destinations but because of the information held by potential tourists. Comprehensive information possessed by potential tourists can create a feeling as if he had never visited the area you want to target. The stronger attachment to prospective travelers with tourist destination the stronger desire to visit the area. It can be seen as an effort to realize the attachment in the form of real action. But this attachment was not directly formed from place information mix of a tourist destination. This is because information obtained by prospective tourists about tourist destination is incomplete as desired by potential tourists.

Entanglement between potential tourists with its target tourist destinations will increase because of the strong positive perceptions arising from the evaluation of place information mix in the minds of potential tourists. The perception in the minds of potential tourists would be stronger if the prospective tourists assess their information in accordance with their cultural characteristics. Ambience tourist destination for prospective tourists contributes significantly shaping a positive perception, so it is important to convey information relating to the physical environment of the tourist destination. Another thing that also needs to be highlighted is the social life of the people in the tourist destination, because one of the things sought by potential tourists when visiting a tourist destination is to feel the hospitality of the local people.

The strong attachment between the potential tourists to the area attractions that will be their destination, and is supported by the strong positive perception of the tourist destinations, will encourage the growth of a desire to visit the tourist destination. Potential tourists also build a desire to visit a tourist destination is not solely due to attractive advertising alone, but also the content of the advertisement that is containing the information sought. Information which is known to increase engagement potential tourists with a tourist destination is information that can increase the pride of potential tourists and information from a tourist destination with regard to the origin prospective tourists.

The desire of potential tourists to visit a tourist destination is possible to be realized if they obtain facilities and information necessary to prepare the readiness of their journey. Ease arrange trips and availability information ittenaryspecific information, such as stores that sell at discounted prices, shopping tips, and so on, is information that can motivate potential tourists to fulfill his desire to visit a tourist destination. It potentially deters potential tourists to fulfill his desire if scheduling their activities with some routine activities.

Supported intention to visit a good perception and a strong sense of attachment between potential tourists with a tourists destination will encourage the emergence of pre-visit action. Intention to visit will be a strong foundation for the formation of pre-visit action because the stronger the intention to visit showed that potential travelers are increasingly willing to sacrifice his routine to fulfill his desire to travel. Good perception of a tourist destination will be the dominant driving force for potential tourists so that they are willing to make sacrifices, financial or non-financial, to visit a tourist destination so it is very important to build a good perception in the eyes of potential tourists. Pre-visit Action which is indicated by the presence of sacrificing made by prospective tourists both financially and non-financially, has been realized significantly by ordering accommodation and transportation.

\section{Conclusion and Discussion}

This study found that pre-visit action potential tourists influenced by the good perception of a tourist destination, the strong desire of potential tourists to visit the tourist destination, and connectiveness among potential tourists to the area to be going. Another finding is the desire to visit tourist destination and connectiveness potential tourists with a tourist destination will be stronger if the perceptions of potential tourists to the tourist destination has grown and intensified. Furthermore, this study found that the perception of potential tourists will be formed if the traveler has a mix of candidate's complete information about a tourist destination.

Pre-visit action, is a strong indication that the prospective tourists will realize the journey, so it is very important for the relevant authorities to provide information on the activities at least one year ahead to allow potential tourists to be able to plan early. Held a promotion, coordination with tourism stakeholders such as hotels, travel agencies, and so on can also be done to attract potential tourists to book accommodation early. However, based on the findings of this study, 
the authority associated with the tourism industry is necessary to ensure that the communication strategy and all the promotional efforts that they do have to inform the things that are valued by potential tourists at the end. The right Place Information Mix will increase the possibility to attract potential tourists, which in turn will improve the competitiveness of a tourist destination.

\section{Limitations and Further Research}

This study has limitations on the number of respondents who became the subject of research. The number of respondents who used also limited by the non-probability sampling method so that this study cannot be used to generalize the behavior of potential Indonesian tourists as a whole. Although the number of respondents involved is not large but still insufficient for the type of analysis performed. This research also has the potential to be developed to find out more about the specific behavior patterns prospective Indonesian tourists. Other variables related to tourist behavior, such as the type of journey, characteristic tourist destination, and the travel group preferences can also be examined to gain a better understanding of the preference to travel in groups or individually.

\section{References}

Blake, R. (1989), 'Integrating Quantitative and Qualitative Methods in Family Research. Families Systems and Health' 7, 411-427. Buhalis, D. (2000), 'Marketing the competitive destination of the future', Tourism Management 21 (1), $97-116$.

Buhalis, D. (1998), 'Strategic use of information technologies in the tourism industry', Tourism Management 19 (5), pp. 409-421. Cooper,C. World Trade Law, Culture: Heritage and Tourism. New York: Adison Wesley Longman Publishing, 2003.

Driscoll, David L.; Appiah-Yeboah, Afua; Salib, Philip; and Rupert, Douglas J. (2007), "Merging Qualitative and Quantitative Data in Mixed Methods Research: How To and Why Not". Ecological and Environmental Anthropology (University of Georgia). Paper 18.

Greene, J., V. Caracelli, and W. Graham (1989),"Toward a Conceptual Framework for Mixed-Methods Evaluation Designs. Educational Evaluation and Policy Analysis" 11:255-274.

Govers, R., Go, F. M. and Kumar, K. (2007), 'Virtual destination Image. A New Measurement Approach', Journal of Tourism Research 34 (4), 977-997.

Goeldner ,Charles R., \& J.R. Brent Ritchie. (2003). Principles, Practices, Philosophies of Tourism. New York: Hoboken, N.J J. Wiley. Gegel, I Putu. (2006). Industry Pariwisata Indonesia :Dalam Globalisasi Perdagangan Jasa GATS WTO, Rafika Aditama, Bandung Gatranews, TMA, (2013), Orang Indonesia Liburan ke LN Meningkat 800!. [Online] Available:http://www.gatra.com/budaya1/wisata/ 32712-orang-indonesia-liburanke-In-meningkat-800.html (17 Juni 2013).

Hudson, S. (2009). Consumer Behavior Related to Tourism. In Consumer Behavior in Travel and Tourism. New York: Routledge Hair, J. F., Anderson, R. E., Tatham, R. L., \& Black, W. C. (2005). Multivariate Data Analysis (6 ed.). Upper Saddle River, NJ: Prentice Hall.

Indonesia Total Arrivals and Departures 2010-2017 di dalam Indonesia Tourism Report 2013 Third Quarter.

Inskeep, Edward. (1991).Tourism Planning: An Integrated and Sustainable Development Approach. New York: John Wiley \& Sons., World Tourism Organization (UNWTO) (2013, January). UNWTO World Tourism Barometer. Web site: http://unwto.org/facts/menu.html

MacKay, Kelly J., and J. Michael Campbell (2004), "A Mixed-Methods Approach for Measuring Environmental Impacts in Nature-Based Tourism and Outdoor Recreation Settings. Tourism Analysis; 9(3):141-152.

Pitana, I Gede dan Putuh, Gayatri (2005), Sosiologi Pariwisata, Andi, Jogjakarta

Soekadijo R.G. (1996). Anatomi Pariwisata, Memahami Pariwisata Sebagai Systemic Linkage. Jakarta: PT Gramedia Pustaka Utama. Ubjan, Jusak, (2008). Pengaruh produk wisata, bauran promosi dan motivasi perjalanan wisata terhadap kunjungan wisata di Kota Ambon, Jurnal Ekonomi Dan Bisnis, volume 6 no 2, 94-107

Rossman, G., and B. Wilson (1991), "Numbers and Words Revisited: Being "Shamelessly Eclectic." Evaluation Review 9(5):627-643.

Weaver \& Opperman, (2000). Tourism Management: Creative - Based Tourism, Milton: Jacaranda Wiley.

WTO (2004). Technical Manual Concepts, Definitions and Classification for Tourism. Madrid: World Tourism Organization. 